Bond University

\title{
ePublications@bond
}

Sports Law eJournal

Faculty of Law

$12-16-2011$

\section{Concussion policies of the National Football League: Revisiting the 'Sport Administrator's Charter' and the role of the Australian Football League and National Rugby League in concussion management}

Annette Greenhow

Bond University, Annette_Greenhow@bond.edu.au

Follow this and additional works at: http://epublications.bond.edu.au/slej

Part of the Entertainment, Arts, and Sports Law Commons

\section{Recommended Citation}

Annette Greenhow. (2011) "Concussion policies of the National Football League: Revisiting the 'Sport Administrator's Charter' and the role of the Australian Football League and National Rugby League in concussion management",, .

http://epublications.bond.edu.au/slej/13

This Journal Article is brought to you by the Faculty of Law at ePublications@bond. It has been accepted for inclusion in Sports Law eJournal by an authorized administrator of ePublications@bond. For more information, please contact Bond University's Repository Coordinator. 


\title{
Concussion policies of the National Football League: Revisiting the 'Sport Administrator's Charter' and the role of the Australian Football League and National Rugby League in concussion management
}

\begin{abstract}
Litigation in the United States against the National Football League (NFL) for failing to protect its players from the effects of multiple concussions raises questions about the role and responsibility of the governing body. The NFL's alleged failure may have exposed it to 'Big Tobacco'-like litigation. Is a governing body ultimately responsible for player-health issues? This article reviews the litigation in the United States and examines the concussion management policies of the Australian Football League (AFL) and the National Rugby League (NRL).
\end{abstract}

\section{Keywords}

professional football, concussion, governing bodies' liability, inherent risk

\section{Disciplines}

Entertainment, Arts, and Sports Law 


\title{
CONCUSSION POLICIES OF THE NATIONAL FOOTBALL LEAGUE: REVISITING THE 'SPORT ADMINISTRATOR'S CHARTER' AND THE ROLE OF THE AUSTRALIAN FOOTBALL LEAGUE AND NATIONAL RUGBY LEAGUE IN CONCUSSION MANAGEMENT
}

\author{
ANNETTE GREENHOW*
}

\begin{abstract}
Litigation in the United States against the National Football League (NFL) for failing to protect its players from the effects of multiple concussions raises questions about the role and responsibility of the governing body. The NFL's alleged failure may have exposed it to 'Big Tobacco'-like litigation. Is a governing body ultimately responsible for player-health issues? This article reviews the litigation in the United States and examines the concussion management policies of the Australian Football League (AFL) and the National Rugby League (NRL).
\end{abstract}

Concussion $^{1}$ in professional sport and especially professional football is a century-old topic, ${ }^{2}$ and one that has appeared as the focal point of many academic and social commentaries. But what has changed, particularly in the last decade, is the gravitational shift towards the apex of professional football - the governing body. ${ }^{3}$ Questions have been asked in forums ranging from media blogs to Congressional Committee Hearings ${ }^{4}$ about the conduct of one of the most recognisable football brands in the world, the NFL, and its handling of player health issues resulting from multiple concussions. Fraudulent concealment, civil conspiracy, negligence, and monopolistic behaviour in failing to properly manage the effects of multiple concussions are just a few of the claims that had been made against the NFL. These allegations have for the first time been aired in legal proceedings in the United States, striking at the heart of the independent and self-regulatory model of professional football governance.

At the 2009 Congressional Hearing, Congresswoman Linda Sanchez predicted just such a legal turn of events by comparing the issue of the handling of concussion in professional football to that of the 'Big Tobacco' litigation of the 1990s:

* Assistant Professor, Faculty of Law, Bond University. This article was first published electronically on 16 December 2011.

1 For the purpose of this article, the definition of concussion adopted at the $3^{\text {rd }}$ International Conference on Concussion will be used: the 'complex pathophysiological process affecting the brain, induced by traumatic biomechanical forces'. See P McCrory, W Meeuwisse, K Johnston et al, 'Consensus Statement on Concussion in Sport, $3^{\text {rd }}$ International Conference on Concussion in Sport, Held in Zurich, November 2008' (2008) 19 (3) Clinical Journal of Sport Medicine 185, 186.

2 In 1904 the issue reached boiling point in the United States when then-President Theodore Roosevelt responded to national anger over the death or serious injury of 19 football players leading to the creation of the National Collegiate Athletic Association as a rules governing body for collegial sport. See J P Kelly and J H Rosenberg, 'Diagnosis and Management of Concussion in Sports' (1997) 48(3) Neurology 575.

3 For the purpose of this article, the term 'governing body' is used to represent the ultimate rulemaker.

4 See House of Representatives Committee on the Judiciary, Government of the United States of America (111th Congress), Hearings on the Legal Issues Relating to Football Head Injuries (Part I E II) (28 October 2009 and 4 January 2010). 
the NFL sort of has this kind of blanket denial or minimizing of the fact that there may be this, you know, link. And it sort of reminds me of the tobacco companies pre-1990s when they kept saying no, there is no link between smoking and damage to your health or ill health effects. And they were forced to admit that that was incorrect through a spate of litigation in the 1990s... ${ }^{5}$

Sure enough, in July and August 2011 two separate legal proceedings were issued against the NFL about this issue. The Maxwell claim was the first, filed on 19 July 2011. ${ }^{6}$ In this claim, 75 retired NFL players sued the NFL, ${ }^{7}$ claiming, inter alia, negligence and fraud over its handling of concussion in professional football during the past four decades. ${ }^{8}$ The following month, on 17 August 2011, another claim was lodged in the United States' District Court in Pennsylvania-the Easterling claim-where seven players have issued class-action proceedings against the NFL alleging concealment, civil conspiracy, and negligence. ${ }^{9}$ These allegations again concern the NFL's handling of concussion and seek to expand the class of claimant into five sub-classes, with playing careers ranging from the 1970s through to current players who have or will suffer concussion on the football field. The Easterling claim seeks the establishment of a Medical Monitoring Program and trust fund to pay for the ongoing medical monitoring of all past, present, and future NFL players. ${ }^{10}$

This article summarises the history of the NFL's approach to concussion management, culminating in the unprecedented move to recognise a Neuro-Cognitive Disability Benefit in the recently negotiated Collective Bargaining Agreement (CBA), ${ }^{11}$ which will compensate eligible players for mild and moderate cognitive impairment. Despite the carefully drafted 'no admission or concession' provision, ${ }^{12}$ the move drew the line in the sand and refuted the mantra 'It's just a concussion' 13 by recognising the serious and possible fatal consequences of multiple concussions in professional football. The plaintiff lawyers in the Easterling claim used this move as an admission by the NFL that it knew of the link between multiple concussions and long term cognitive problems. ${ }^{14}$

5 Ibid 116

$6 \quad$ Maxwell et al v National Football League et al (Superior Court of California, County of Los Angeles, BC 465842, 19 July 2011).

7 The proceedings also make claims against NFL Properties (the corporate entity who approves equipment licensing and promotion for all NFL teams) and Riddell Inc and its subsidiaries (the designers, manufacturers and suppliers of football equipment, specifically helmets). For the purposes of this article, only the claim against the NFL will be reviewed.

8 Maxwell et al v National Football League et al (Superior Court of California, County of Los Angeles, BC 465842, 19 July 2011).

9 Easterling et al v National Football League, (Pennsylvania Eastern District Court, 2:2011cv05209, 18 August 2011).

10 Ibid 1, Complaint against the National Football League, $<$ http://docs.justia.com/cases/federal/district-courts/pennsylvania/paedce/2:2011cv05209/435351/1/> [58]-[67].

11 Collective Bargaining Agreement between the National Football League Management Council and the National Football Leagues Players Association, 4 August 2011, Article 65 (Neuro-Cognitive Disability Benefit).

12 Ibid s 2.

13 See Alexander Hecht, 'Legal and Ethical Aspects of Sports-related Concussion: Merril Hoge Story' (2002) 12 Seton Hall Journal of Sport Law 27.

14 Easterling et al v National Football League, (Pennsylvania Eastern District Court, 2:2011cv05209, 18 August 2011), 1, Complaint against the National Football League, $<$ http://docs.justia.com/cases/federal/district-courts/pennsylvania/paedce/2:2011cv05209/435351/1/> [2]. 
This article also examines the claims against the NFL and considers the position of the Australian Football League (AFL) and National Rugby League (NRL) ${ }^{15}$ as the governing bodies responsible for the management and supervision of their respective codes. It asks whether the actions against the NFL are unique to the particular northern hemisphere context, or whether any parallels can be drawn to these Australian codes. If the NFL claims do raise concern about the management of multiple concussions in professional football in Australia, the article considers whether this necessitates a review of the Sport Administrator's Charter, ${ }^{16}$ particularly with respect to the duty of care, and analyses the possibility of similar claims in Australia. ${ }^{17}$ Assuming a duty of care could be established, could it be argued that governing bodies in Australia should have known of the international medical research linking multiple concussions to degenerative cognitive disorders? More specifically, as the bodies vested with the supervisory and regulatory roles of their respective codes, would the responses of the AFL and NRL over the past decade be sufficient to satisfy an examination of their actions under the legal-standards microscope?

\section{The Medical Research}

Medical research in the United States over the potentially fatal effects of multiple concussions has been gaining momentum in the last decade. What began as an almost routine autopsy conducted by Dr Bennet Omalu ${ }^{18}$ in 2002 on the body of a deceased NFL football player ${ }^{19}$ led to the extraordinary finding that formed the basis of the Maxwell and Easterling claims. ${ }^{20}$ The findings by Dr Omalu identified the disease Chronic Traumatic Encephalopathy (CTE), also known as 'punch drunk syndrome', ${ }^{21}$ as a 'significant contributing factor' ${ }^{22}$ to the death of the former NFL player. ${ }^{23}$

15 This article focuses on Australian Rules football and rugby league, as these codes self-govern and have the power to individually amend their rules in Australia. In comparison, rugby union in Australia is governed by Australian Rugby Union, a member of the International Rugby Board (IRB). Soccer in Australia is regulated by the Football Federation of Australia and member of Fédération Internationale de Football Association (FIFA). These codes do not have the power to individually amend their own rules in Australia.

16 See Hayden Opie, 'The Sport Administrator's Charter: Agar v Hyde' (2002) 12 Seton Hall Journal of Sport Law 199.

17 For example, a limited duty could arise in situations where there is increasing concern in medical circles, triggering an obligation on the part of the governing body to increase efforts in reporting and investigating sports related injuries. In this way, the possibility of similar claims may depend on the state of gathered knowledge in Australia about the effects of multiple concussions. Ibid 16.

18 Forensic Pathologist, University of Pittsburgh.

19 Mike Webster, who played 150 games for the Pittsburgh Steelers, retired at 38 and died at 50 of a heart attack. See Joseph Hanna and Daniel Kain, 'NFL's Shaky Concussion Policy Exposes the League to Potential Headaches' (2010) 28(3) Entertainment and Sports Lawyer 9.

20 See Easterling v National Football League, (Pennsylvania Eastern District Court, 2:2011cv05209, 18 August 2011), 1, Complaint against the National Football League,


[99].

21 CTE was first discovered in boxers, jockeys and wrestlers who sustained multiple blows to the head. See R Cantu, 'Chronic Traumatic Encephalopathy in the National Football League Play' (2007) 61 Neurosurgery 223, 224.

22 Alan Schwartz, 'Expert Ties Ex-Players' Suicide to Brain Damage from Football', NY Times (online), 18 January 2007, <http://www.nytimes.com/2007/01/18/sports/football/18waters.html $>$.

23 Over the next 5 years, Dr Omalu participated in three more autopsies of retired NFL players and found CTE present in each case, as well as evidence of deteriorated cognitive function and psychiatric symptoms. See Bennet I Omalu et al, 'Chronic Traumatic Encephalopathy in a National Football League Player' (2005) 57 Neurosurgery 128; Bennet I. Omalu et al, 'Chronic Traumatic 
CTE is a progressive degenerative disease of the brain and is linked to those with a history of repetitive concussion, triggering progressive degeneration of the brain tissue, which in turn leads to the build-up of an abnormal protein called tau. The brain degeneration is associated with memory loss, confusion, impaired judgment, paranoia, impulse control problems, aggression, depression, and, eventually, progressive dementia. ${ }^{24}$ The discovery by Dr Omalu was not the first time the issue of CTE had been raised in association with multiple concussions in football. ${ }^{25}$ However, what was extraordinary about the findings was the subsequent reaction (some might argue, inaction) of the NFL, culminating in a Congressional Hearing and the instigation of the Maxwell and Easterling claims.

A number of leading neuropathologists have published widely in the area of sport-related concussion. Most notably, and with a particular emphasis on football, Dr Robert Cantu ${ }^{26}$ found the leading cause of athletic death was concussion, and that there was no such thing as a 'minor concussion'. ${ }^{27}$ Dr Cantu developed return-to-play guidelines in 1986, ${ }^{28}$ has conducted many studies on sport-related concussion, ${ }^{29}$ and co-founded the Sports Legacy Institute Injury Centre at Boston University. ${ }^{30}$ Another leading neuropathologist, Dr Kevin Guskiewicz, ${ }^{31}$ created the National Athletic Trainers Association Guidelines in 2004. ${ }^{32}$ His subsequent research in 2005 found that three or more concussions led to a five-fold prevalence of mild cognitive impairment. ${ }^{33}$ In more recent times, Dr Ann McKee ${ }^{34}$ has

Encephalopathy in a National Football League Player: Part II' (2006) 59 Neurosurgery 1086. The recent autopsy performed by Dr Omalu and Dr Bailes in June 2010, in which the doctors diagnosed CTE in the case of a football player for the 22nd time, was the first case in which the deceased player was active in the NFL immediately prior to his death. See Hanna and Kain, above n 19.

24 Sports Legacy Institute, Chronic Traumatic Encephalopathy (2011), Center for the Study of Traumatic Encephalopathy, Boston University $<$ http://www.sportslegacy.org/index.php/cte-andconcussions/what-is-cte>.

25 The Maxwell claim documents 36 entries from the 1890s through to 1993 and referred to research conducted by world renowned neuropathologist Dr Robert Cantu. See Maxwell et al v National Football League et al (Superior Court of California, County of Los Angeles, BC 465842, 19 July 2011), 1, Complaint against the National Football League, [117].

26 Director, National Centre for Catastrophic Sports Injury Research and Centre for Chronic Traumatic Encephalopathy, Boston University.

27 See Hecht, above n 13, 38.

28 Robert Cantu, 'Guidelines to Return to Contact After Cerebral Concussion' (1986) 14 The Physician and Sports Medicine 75.

29 The most recent study found that American football is the sport associated with the greatest number of traumatic brain injuries. Over a 10 year span from 2000 to 2009, there was an average of 6.2 cerebral injuries annually with incomplete recovery. See Daniel Daneshvar, Christopher Nowinski, Ann McKee and Robert Cantu, 'The Epidemiology of Sport-Related Concussion' (2011) 30(1) Clinics in Sports Medicine 3, 6.

30 The Sports Legacy Institute Injury Centre at Boston University was co-founded with Christopher Nowinski in partnership with the Boston University School of Medicine Center for the Study of Traumatic Encephalopathy (CSTE). See Sports Legacy Institute, Our Team (2011), $<$ http://www.sportslegacy.org/index.php/about-sli/our-team>.

31 Injury Prevention Research Centre, University of North Carolina.

32 Jennifer Ann Heiner, 'Concussion in the National Football League: Jani v Bert Bell/Pete Rozelle NFL Player Ret. Plan and a Legal Analysis of the NFL's 2007 Concussion Management Guidelines' (2008) 18 Seton Hall Journal of Sports \& Entertainment Law 255, 269.

33 Kevin M Guskiewicz et al, 'Association between Recurrent Concussion and Lat-Life Cognitive Impairment in Retired Professional Football Players' (2005) 57 Neurosurgery 722.

34 Department of Neuropathology, Bedford and Departments of Neurology and Pathology, Boston University School of Medicine. 
conducted studies at Boston University on retired NFL players, and discovered distinct evidence of CTE. 35

\section{NFL's Concussion Management Response before the Congressional Hearing}

Critics of the NFL have suggested that it failed to accept the results of the independent research and instead engaged upon a campaign to minimise the issue. ${ }^{36}$ In 2011, this complaint was repeated in the Maxwell and Easterling claims. With the body of scientific evidence amassing, and leading scientists and the media coining the phrase a 'concussion crisis' $^{\prime}{ }^{37}$ it appears that it was not until the Congressional Hearings that the NFL stepped up a gear and implemented significant reforms.

The NFL's first venture into the study of concussion began in 1994 when then-Commissioner Paul Tagliabue established the Mild Traumatic Brain Institute (MTBI) Committee and appointed Dr Elliott Pellman as its chair. A 13-part study was conducted and the MTBI Committee published its findings in 2003 and 2004. These studies were relied upon by the NFL in formulating its Concussion Management Guidelines in 2007. The critics were vocal and complained that the NFL research was fundamentally flawed ${ }^{38}$ but very little of substance was done.

Critics took particular note of the results published in parts 4, 6 and 7 of the MTBI Committee findings. Part 4 analysed the effect of repeat injuries and concluded that, contrary to other non-NFL studies, there was no increased risk of repeat concussion and no slower recovery period for those players who had a history of concussion. This conclusion drew the immediate criticism of Dr Guskiewicz, who argued that the study was flawed in terms of its design, data collection, and analysis, and suggested that the findings downplayed the danger of repeat concussions. Part 6 of the findings examined the results of baseline testing, but was criticised on the basis that it was incomplete, with missing tests and a 22 per-cent player participation rate. ${ }^{39}$ Part 7 of the findings reviewed the return-to-play guidelines and contradicted the earlier findings of Dr Guskiewicz that a player was exposed to an increased risk if he returned to play within 7 to 10 days of repeat injury. ${ }^{40}$

Dr Guskiewicz argued that the results were incomplete and questioned methodology that had been applied in the NFL funded research. ${ }^{41}$ In 2007, Dr Guskiewicz was reported to have said:

I think that some of the folks within the N.F.L. have chosen to ignore some of these earlier findings, and I question how many more, be it a large study like ours, or single-case

35 See Ann McKee, ‘Chronic Traumatic Encephalopathy in Athletes Progressive Tauopathy After Repetitive Head Injury’ (2009) 68 Journal of Neuropathology \& Experimental Neurology 709, 732.

36 See Alan Schwartz above $\mathrm{n} 22$.

37 'I have never seen this disease in the general population, only in these athletes ... It's a crisis, and anyone who doesn't recognize the severity of the problem is in tremendous denial.' Dr Ann McKee as reported in the Boston Globe. See Bob Hohler, 'Major Breakthrough in Concussion Crisis' The Boston Globe (online), 27 January 2009

$<$ http://www.boston.com/sports/other_sports/articles/2009/01/27/major_breakthrough in_concussio n_crisis/?page $=2>$.

38 See Heiner, above n 32.

39 Peter Keating, 'Doctor yes' ESPN The Magazine (online), 24 October 2006, $<$ http://espn.go.com/expn/print?id=2636795 $>$.

40 See Heiner, above $\mathrm{n} 32$.

41 See Keating, above n 39, 4, 5. 
studies like Terry Long, Mike Webster, whomever it may be, it will take for them to wake up. ${ }^{42}$

In the response to these criticisms, the NFL co-ordinated the first NFL Concussion Summit in June 2007, at which it adopted the NFL Concussion Management Guidelines. But these were not the significant reforms critics had hoped for. Despite warnings from medical experts at the Summit of the increased risk of cognitive impairment from multiple concussions, the NFL published a player informational pamphlet in August 2007 which stated that there was 'no magic number' as to how many concussions were too many. ${ }^{43}$ This contradicted the published research of Dr Guskiewicz ${ }^{44}$ and the advice of experts at the Summit. ${ }^{45}$

The NFL then commissioned the University of Michigan to conduct research into the effects of concussion, with the results published in $2009 .{ }^{46}$ The results were alarming and found that NFL players were 19 times more likely to develop Alzheimer's or similar memory-loss diseases than members of the same class in the general population. Not surprisingly, this research captured the attention of the media, with widespread headline grabs and television coverage, including coverage in Australia in October 2009.47

In what must have been its annus horribilis, and almost simultaneously with the release of the University of Michigan results, the first part of the Congressional Hearing was convened to focus on whether multiple concussions contributed to the early onset of cognitive decline. ${ }^{48}$ The Committee took note of representations made by Dr Ira Casson ${ }^{49}$ of the NFL, who denied any potential links between multiple concussions and CTE or other cognitive problems. These repeated denials, despite the independent scientific evidence to the contrary, led to the analogy with the 'Big Tobacco' type litigation, and to sensational headline grabs such as 'Concussion and Cigarettes'. ${ }^{50}$ It is also possible that it ignited the litigation lawyers' flame, ultimately resulting in the filing of the Maxwell and Easterling claims.

In summary, the following provides a snapshot of some of the NFL responses to independent medical research up to the Congressional Hearing:

42 See Schwartz, above $\mathrm{n} 22$

43 See Roger Goodell and Ted Johnson, 'Concussion and Congress and The Future Game', The Fifth Down (blog), The New York Times (online), 1 November 2009

<http://fifthdown.blogs.nytimes.com/2009/11/01/concussions-and-congress-and-the-future-game/>.

44 See Hanna and Kain, above n 19,10.

45 Experts advised the NFL that players with multiple concussions are at greater risk of injury and developing long-term cognitive problems. Ibid 9.

46 Ibid 10

47 Lee Lin Chin, SBS World News Australia, 18 October 2009.

48 At the time, Michael V Kaplen, president of the Brain Injury Association of NY State, called upon Congress to conduct hearings regarding the medical research on concussions relied upon in the NFL's return to play guidelines. He raised questions about the qualifications of the MTBI Committee Chair, Dr Elliot Pellman. See Keating, above n 39.

49 See above $\mathrm{n} 4,2$.

50 See John Culhane, 'Concussions and Cigarettes: A new lawsuit claims the NFL is like Big Tobacco. Does the case have merit? Slate (online) 26 July 2011, <http://www.slate.com/articles/sports/sports_nut/2011/07/concussions_and_cigarettes.html>. 


\begin{tabular}{|c|c|}
\hline INDEPENDENT RESEARCH & NFL RESPONSE \\
\hline $\begin{array}{l}\text { 2002-2005: clinical and neuropathological } \\
\text { studies found connection between multiple } \\
\text { concussion and cognitive problems. }{ }^{51} \\
\text { 2005-2006: Reports of Dr Bennet Omalu } \\
\text { reporting on evidence of CTE in brain } \\
\text { tissue of deceased NFL Players. }{ }^{52}\end{array}$ & $\begin{array}{l}\text { NFL MTBI Committee denied knowledge of a } \\
\text { link and claimed that several more years of } \\
\text { research was required to reach a definitive } \\
\text { conclusion. Published Part } 4 \text { of its own } \\
\text { studies. }{ }^{53}\end{array}$ \\
\hline $\begin{array}{l}\text { 2005: Report of Dr Guskiewicz finding the } \\
\text { association between recurrent concussion } \\
\text { and later-life cognitive impairment in } \\
\text { retired professional football players }{ }^{54}\end{array}$ & $\begin{array}{l}\text { NFL MTBI Committee member Dr Mark } \\
\text { Lovell stated 'We want to apply scientific } \\
\text { rigor to this issue to make sure that we're } \\
\text { really getting at the underlying cause of } \\
\text { what's happening... You cannot tell that from } \\
\text { a survey.' } 55\end{array}$ \\
\hline $\begin{array}{l}\text { 2008: Report of Dr Ann McKee discovered } \\
\text { evidence of CTE in the brain tissue of two } \\
\text { deceased NFL players, concluding that } \\
\text { there was overwhelming evidence that CTE } \\
\text { is the result of repeated sub-lethal brain } \\
\text { trauma. }{ }^{56}\end{array}$ & $\begin{array}{l}\text { In the material presented to the Congressional } \\
\text { Committee Hearing in 2009, the then MTBI } \\
\text { Committee Chair, Dr Ira Casson, was } \\
\text { reported to have denied the link on six } \\
\text { separate occasions, stating that it had never } \\
\text { been scientifically, validly documented. }{ }^{57}\end{array}$ \\
\hline
\end{tabular}

\section{NFL Sea Change after the Congressional Hearings}

In what became a defining moment or 'sea change' 58 in the history of the NFL's handling of concussion, the post-congressional hearing period led to radical reforms within the NFL. This translated to a multi-faceted approach to the issue of multiple concussions, covering a renewed commitment to independent research, education, and rule changes designed to protect player health. The NFL immediately suspended all NFL in-house research by the MTBI Committee, made a donation of $\$ 1$ million to the Boston University's Centre for the Study of Cognitive Traumatic Encephalopathy ${ }^{59}$ and embarked upon a series of internal rule changes. It also led to policy change, in prescribing mandatory medical assistance by an independent local doctor at all games, to handle return-to-play decisions. Not surprisingly, new specialist neurologists were appointed to the NFL MTBI Committee. ${ }^{60}$

51 See Hanna and Kain, above n 19, 9.

52 See Bennet I Omalu et al, 'Chronic Traumatic Encephalopathy in a National Football League Player' (2005) 57 Neurosurgery 128; Bennet I Omalu et al, 'Chronic Traumatic Encephalopathy in a National Football League Player: Part II' (2006) 59 Neurosurgery 1086.

53 See Elliot Pellman et al, 'Concussions in Professional Football: Repeat Injuries - Part 4' (2004) 55(4) Neurosurgery 860.

54 See Guskiewicz, above $\mathrm{n} 33$.

55 See Schwartz, above $\mathrm{n} 22$.

56 See McKee, above $\mathrm{n} 35$.

57 See above $n$ 4, 10.

58 See Hanna and Kain, above n 19, 10.

59 This amount has increased to $\$ 6$ million according the NFL Health and Safety website - see $<$ http://nflhealthandsafety.com $>$.

60 Dr Hunt Batier and Dr Richard Ellenbogen, critics of the prior work of the MTBI Committee, were subsequently appointed. See Hanna and Kain, above n 19, 12. 
The release of mandatory guidelines including provisions that prohibited a player from returning to play on the same day if the player had lost consciousness after the First Concussion Summit in 2007 were certainly a positive change in the NFL's attitude. It was not until after the Congressional Hearings in 2009, however, that any player who suffered a concussion, regardless of whether the player lost consciousness, was prevented from returning to play in the same game.

In any case, the guidelines have been criticised as 'quintessentially political' in nature, designed to protect the teams rather than the players. ${ }^{61}$ The guidelines provide a minimum standard for the team doctor, designed to apply to the playing field, rather than applying in a court of law. ${ }^{62}$ As evidenced by the filing of the Maxwell and Easterling claims, the guidelines did not prevent litigation. If the claims proceed, and assuming a duty of care is proven, it will be interesting to see what evidentiary value the guidelines carry in determining issues surrounding the standard of care owed by the NFL.

On the education front, the NFL has since embarked upon a campaign designed to educate players about the effect of multiple concussions by establishing a health and safety website and placing concussion awareness posters in the locker rooms of all teams. Updated informational pamphlets were printed and distributed to players with greater emphasis on the risk of concussion.

\section{Release and Waiver -New Article 65 Neuro-Cognitive Disability Benefit}

In the recent settlement of the NFL player lockout ${ }^{63}$ and successful conclusion to the Collective Bargaining negotiations, the NFL has now entered into a new CBA with the NFL Players Association until 2020. Significantly, a new disability benefit has been included in the CBA specifically dealing with neuro-cognitive disorders. The existing disability plan already entrenched in the NFL structure has been extended to include this new benefit for eligible players who have a permanent neuro-cognitive impairment but who do not currently receive a benefit. ${ }^{64}$

To be eligible for the new benefit, the player must satisfy a number of requirements. ${ }^{65} \mathrm{~A}$ precondition to entitlement is that the player must have first signed a release (in a form to be agreed upon) and covenant not to sue the NFL. The Article goes further to include a comprehensive denial of liability in the following terms:

The parties acknowledge and agree that the provision of the benefit under this Article shall not be construed as an admission or concession by the NFL that NFL football caused or causes in whole or in part, the medical conditions covered by the benefit, or as an

61 See Hecht, above n 13, 52.

62 Ibid 54

63 On 11 March 2011, the players union (the NFLPA) announced they had 'decertified' and were no longer taking part in collective bargaining over a new agreement between the league and players. This resulted in a suspension of all NFL activities and all dealings between players and clubs. See Simon Evans, 'NFL announces lockout of players', Reuters (online), 12 March 2011, <http://www.reuters.com/article/2011/03/12/us-nfl-lockout-idUSTRE72B25I20110312>.

64 Article 65 supplements the 88 Plan benefits which apply to those players diagnosed with dementia (as opposed to early stage cognitive disorders). The benefit payable depends upon the degree of impairment and settles on a figure of not less than $\$ 1500$ per month for mild impairment and $\$ 3000$ per month for moderate impairment, with incremental increases from 2013. See Collective Bargaining Agreement, above n 11, 247-248.

65 Of note: to be under the age of 55 and to have played at least one credited season after 1994. Ibid 247. 
admission of liability or wrongdoing by the NFL, and the NFL expressly deny any such admission, concession, liability or wrongdoing. ${ }^{66}$

No doubt the lawyers acting on behalf of the NFL had little choice but to include such a broad disclaimer.

In addition to the Article 65 Benefit, the NFL is now a vocal supporter of the roll-out of state and federal legislation in the United States regulating concussion policies for school-aged children. ${ }^{67}$ The benevolence of the NFL in 2011 is a positive and, some might argue, long overdue recognition of its iconic status within American society. Such benevolence was not, however, timely enough to insulate the NFL from the Maxwell and Easterling claims.

\section{The Maxwell Claim}

The 81-page Complaint against the National Football League filed in the Superior Court of California ${ }^{68}$ provides an explanation, albeit from the plaintiff's perspective, for the causal link between the medical research surrounding CTE, the NFL's duty to protect its players, the alleged failure in that duty, and the subsequent damages. The claim also alleges fraudulent concealment based on the repeated denials by the NFL of independent medical research linking CTE to multiple concussions in football. It suggests that the NFL has been on notice of the harmful effects of multiple concussions since the 1920s. ${ }^{69}$ It goes further to allege direct notice of the serious implications of multiple head injuries contributing to cognitive decline in later life since at least $2002 .{ }^{70}$

The claim provides a short summary of the history of the NFL from its establishment in 1920 to its current-day operations, grossing $\$ 9$ billion per year and involving 32 separate franchise teams. ${ }^{71}$ The claim points out that the NFL is 'big business'. It lists the personal details of the 75 retired players making the claim, together with details of their playing histories and subsequent medical conditions, allegedly linked to the multiple concussions suffered by each player. ${ }^{72}$ The claim also identifies their current symptoms and, where applicable, claims a loss of consortium by the players' wives..$^{73}$ The claim seeks legal remedies including damages for negligence and fraudulent concealment. The allegations against the NFL are framed in the strongest of terms and strike at the heart of the integrity and moral fabric of the organisation. ${ }^{74}$

\section{Negligence}

The claim details the allegations surrounding the duty of care owed by the NFL to both its players and the public. In support of this allegation, the claim asserts that the NFL, through its iconic status and monopolistic power, overtly undertook a duty to study concussion on behalf of its members and players. This duty extended to the obligation to ensure that the

66 Ibid.

67 As at August 2011, 28 states have passed concussion laws designed to prescribe mandatory concussion policies for school aged children. The Federal Concussion Treatment and Care Tools Act 2010 was passed in November 2010.

68 Maxwell et al $v$ National Football League et al (Superior Court of California, County of Los Angeles, BC 465842, 19 July 2011), 1, Complaint against the National Football League.

69 Ibid [111].

70 Ibid [133].

71 Ibid [88] - [95].

72 Ibid [149]- [523].

3 Ibid [587]-[589].

74 Ibid [147] [148] alleging that the NFL acted with callous indifference, wilfully, wantonly, egregiously with reckless abandon and with a high degree of moral culpability. 
research and education of football industry injuries was imparted to physicians, trainers, coaches and injured players, as well as the public at large. The claim asserts that the players relied on the NFL to protect them. ${ }^{75}$

The duties and alleged breaches made in the claim are outlined in the following table:

\begin{tabular}{|c|c|}
\hline DUTY $^{76}$ & BREACH $^{77}$ \\
\hline To protect the plaintiffs on the playing field. & $\begin{array}{l}\text { Failure to enact rules, policies and } \\
\text { regulations to best protect its players. } \\
\text { Failure to institute acclimation requirements } \\
\text { or procedures to ensure the proper } \\
\text { acclimation of the NFL players before they } \\
\text { participated in practice or games. } \\
\text { Failure to regulate or monitor practices, } \\
\text { games and medical care so as to minimise } \\
\text { long-term risks associated with cognitive } \\
\text { brain injuries. } \\
\text { Failure to require that an adequate } \\
\text { concussion brain injury history be taken of } \\
\text { NFL players. }\end{array}$ \\
\hline $\begin{array}{l}\text { To educate NFL players, trainers, physicians } \\
\text { and coaches about CTE and/or concussion } \\
\text { injury. }\end{array}$ & $\begin{array}{l}\text { Failure to invoke league wide guidelines } \\
\text { policies and procedures regarding the } \\
\text { identification and treatment of concussive } \\
\text { brain injury and return-to-play. } \\
\text { Failure to properly inform players of the } \\
\text { health risks associated with concussive } \\
\text { injury. } \\
\text { Failure to warn of the harm of repetitive } \\
\text { concussion injury. }\end{array}$ \\
\hline $\begin{array}{l}\text { To have strict return-to-play guidelines to } \\
\text { prevent CTE and/or concussion injury. }\end{array}$ & Failure to invoke league-wide guidelines. \\
\hline $\begin{array}{l}\text { To promote a 'whistleblower' system where } \\
\text { teammates would bring to the attention of } \\
\text { the trainers and coaches that another player } \\
\text { suffered concussion. }\end{array}$ & $\begin{array}{l}\text { Failure to provide complete, current and } \\
\text { competent information and directions to the } \\
\text { NFL athletic trainers, physicians and coaches } \\
\text { regarding concussive brain injuries and its } \\
\text { prevention, symptoms and treatment. }\end{array}$ \\
\hline
\end{tabular}

75 Ibid [108] - [110]. It is interesting to note the parallels between the decision to participate and the individual's perception of the acceptability of risk, the benefits involved and the trust in the people organising the sport, as noted in Chicken and Posner's Philosophy of Risk and specifically in relation to professional football, by Hayden Opie. See Opie, above n 16, 212.

76 Maxwell et al v National Football League (Superior Court of California, County of Los Angeles, BC 465842, 19 July 2011), 1, Complaint against the National Football League [110].

$77 \quad$ Ibid [533]. 


\begin{tabular}{|l|l|}
\hline $\begin{array}{l}\text { To design rules to eliminate the risk of } \\
\text { concussion during games and/or practices } \\
\text { and rules penalties for players who use their } \\
\text { head hit or tackle. }\end{array}$ & $\begin{array}{l}\text { Failure to establish any guidelines or policies } \\
\text { to protect mental health and safety of its } \\
\text { players.78 } \\
\text { Failure to implement standardised post } \\
\text { concussion guidelines by failing to enact } \\
\text { rules to decrease the risk of concussions } \\
\text { during games or practices. }\end{array}$ \\
$\begin{array}{l}\text { Failure to implement mandatory rules that } \\
\text { would prevent a player who suffered a mild } \\
\text { dramatic brain injury from re-entering a } \\
\text { game and being placed at further risk of } \\
\text { injury.79 }\end{array}$ \\
\hline $\begin{array}{l}\text { To promote research into and find a cure of } \\
\text { CTE and the effects of concussion industry } \\
\text { over a period of time }\end{array}$ & $\begin{array}{l}\text { Violated the California Business and } \\
\text { Professional Code } 80 \text { by engaging in practices } \\
\text { that restrain the development of good science } \\
\text { on the problem and epidemic of concussion } \\
\text { injuries. }\end{array}$ \\
\hline $\begin{array}{l}\text { To the State governments, local sports } \\
\text { organisations, all-American rules football } \\
\text { leagues, players and the public at large to } \\
\text { protect against the long-term effects of CTE } \\
\text { and/or concussion injury. }\end{array}$ & $\begin{array}{l}\text { Failure to warn the public and other } \\
\text { American rules football leagues of the health } \\
\text { risks associated with multiple concussions. } \\
\text { Failure to warn of the harm of repetitive } \\
\text { concussion injuries. }\end{array}$ \\
\hline
\end{tabular}

\section{Fraud}

The Maxwell claim is particularly scathing of the NFL's conduct in relation to the fraud claim, suggesting that the NFL embarked upon a scheme of fraud by denying knowledge of the link between concussion and cognitive decline. ${ }^{81}$

The claim goes into some detail outlining the history of scientific research into CTE. References are made to the Omalu, Cantu, Guskiewicz and McKee research, as well as to the actions by the NFL in setting up the MTBI Committee. The claim alleges that the NFL made material misrepresentations to its players, former players, Congress, and the public that there was no link between concussion and later-life cognitive injury. Such representations were allegedly relied upon by the plaintiffs in failing to secure the proper care for their injuries, to their detriment.

\section{The Easterling Claim}

The Easterling claim differs from the Maxwell claim in two respects. The first is that the Easterling claim seeks certification of a nationwide class action against the NFL for negligence

\footnotetext{
Ibid [531].

Ibid [528].

80 Ibid [525]. The California Business and Professional Code, Section 17001, states that the purpose of the chapter is to safeguard the public against the creation of the perpetuation of monopolies and to foster and encourage competition by prohibiting unfair dishonest deceptive destructive fraudulent and discredit true practices by which fair and honest competition is destroyed or prevented.

81 Ibid [125].
} 
and wrongful conduct. The second is that the claim seeks remedies that include a medical monitoring program and trust fund for the purposes of testing and monitoring vulnerable players, past, present and future.

The claim was launched by seven players allegedly representative of classes spanning professional playing careers from the 1970s to the 2000s. The claim alleges that the NFL has been on notice of the link between multiple concussions and cognitive decline for at least 35 years. In the light of its supervisory and management role, coupled with the high incidence of concussion since the 1970s, the claim alleges that the NFL knew or ought to have known that a history of multiple concussions had been associated with a greater risk of future brain injury.

The claim alleges that the CBA on 4 August 2011 is evidence that the NFL is aware of the link, but that during the 35-year period the NFL continuously and vehemently denied the link to the public. ${ }^{82}$ Presumably the evidence referred to is the inclusion of the new Neuro-Cognitive Disability Benefit in the CBA. ${ }^{83}$ The claim further outlines details of the NFL denials of the link and refers to NFL publications, sponsored medical studies, representations to Congress and media comments in support of its claim that the NFL denied the link.

The claim alleges that the plaintiffs became aware of the actions of the NFL when the University of Michigan study was released in 2009. It is alleged that until that date, the plaintiffs did not have a reasonable basis to know or believe that harm was caused by the NFL's neglect, concealment, or misconduct. Presumably, this has been included to circumvent any arguments that the claims may be statute-barred, and invokes the 'discovery rule' so that the limitation period runs from the date the claimant knew or reasonably should have known. ${ }^{84}$

The claim alleges that the NFL has failed to monitor or study whether and when a player has suffered a concussion ${ }^{85}$ and seeks the certification of a 'Medical Monitoring National Class'. If awarded, the ramifications for the NFL will be significant. The proposed design includes all past, present, and future NFL players who have suffered, or are likely to suffer, concussion and provides access to a trust fund to pay for the medical monitoring costs. Given the number of reported concussions in NFL, the number of players could be in the thousands. ${ }^{86}$ The class is divided into two groups, and uses the date of the claim as the benchmark. Those retired and current players who had, as at 17 August 2011, suffered a concussion but had not, as at that date, developed or experienced long term problems fall into the first group. The second group includes all current and future NFL players who, from 17 August 2011 onwards, suffer a concussion. If successful, the Medical Monitoring Program will require that players be

82 Easterling et al $v$ National Football League, (Pennsylvania Eastern District Court, 2:2011cv05209, 18 August 2011), 1, Complaint against the National Football League, $<$ http://docs.justia.com/cases/federal/district-courts/pennsylvania/paedce/2:2011cv05209/435351/1/> [2].

83 See Collective Bargaining Agreement, above $n 11$.

84 See Hanna and Kain, above n 19, 12.

85 Easterling et al v National Football League, (Pennsylvania Eastern District Court, 2:2011cv05209, 18 August 2011), 1, Complaint against the National Football League, $<$ http://docs.justia.com/cases/federal/district-courts/pennsylvania/paedce/2:2011cv05209/435351/1/> [65].

86 Last season alone saw concussions increase by $21 \%$. See Associated Press, 'Concussions reported in NFL up 21 percent from last season' NFL (online), 13 December 2010, $<$ http://www.nfl.com/news/story/09000d5d81cdf2d6/article/concussions-reported-in-nfl-up-21percent-from-last-season>. 
tested to determine whether the player is officially healthy enough to return-to-play and/or reduce the risk of a player suffering long-term injuries.

No details are given as to the type of monitoring suggested and, by implication, it must be designed to extend the current model of baseline testing prescribed by the NFL. The current testing model in the US is the baseline test at preseason and post injury, to test the cognitive function of the player. The current baseline testing can be done in a computerised fashion which costs approximately $\$ 1000$ per team. ${ }^{87}$

\section{Possible NFL Responses}

Speculation has been rife in the United States about this possible litigation and many commentators have been quick to forecast possible defences available to the NFL. Not surprisingly, the threshold issue for the plaintiffs to prove is that the NFL owed a duty of care. Arguments of special relationship or some form of joint employment have been raised, supporting the obligation to use reasonable care in protecting the players. ${ }^{88}$

The obvious defence of voluntary assumption of risk has been suggested-that the players knew or ought to have known that the risk of head injuries is an inherent and obvious risk in a full contact sport like football. ${ }^{89}$ Implicit in this defence is the requisite degree of knowledge required in order to invoke the full force of the defence. Actual, as opposed to constructive knowledge of the risks, is required. The defence therefore requires answers to questions surrounding the extent of players' knowledge as to the effect of multiple concussions and whether they were placed in a more vulnerable position to be at a higher risk of CTE or other cognitive disorders. A counter-argument to this defence has been raised to suggest that the NFL concealed the dangers by, inter alia, publicly denying the risks and misleading players into a false sense of security..$^{90}$ Applying the American version of the cost/benefit analysis (the 'Hand Formula'), ${ }^{91}$ where the burden of prevention (borne by the NFL) is argued to be less than the probability of loss (suffered by the players), the burden should not rest on the players but rather on the NFL. This approach seems consistent with views expressed based on principles of economic efficiency and the 'least-cost avoiders'. ${ }^{92}$

Another defence is that of contributory negligence; unlike the assumption of risk defence, actual knowledge of risk is not required for contributory negligence. ${ }^{93}$ The NFL could argue that players contributed to their own injuries by failing to report their symptoms, or the severity of their symptoms, and returning to play prematurely. ${ }^{94}$ A survey conducted in 2010 discloses that close to $10 \%$ of players admitted that they had either failed to report or under-

87 These figures were current as at 2002. See Hecht, above n 13, 50. In Australia, the cost of computerised baseline testing is $\$ 550$ per team up to 50 athletes and $\$ 110$ each set of 10 athletes thereafter. Cogstate Clinical Trials, 'Buy Sport' (2011) Cogstate (online),

$<$ http://www.cogstate.com/index.cfm?objectid=1CF8DAB4-E081-282F-9843A292B46C9A2E >.

88 See Heiner, above n 32, 280.

89 Michael McCann, 'Concussion lawsuit could cost NFL whether decided in or out of court' Sports Illustrated (online), 19 August 2011, <http://sportsillustrated.cnn.com/2011/writers/michael mccann/08/19/concussion.lawsuit/index.html $>$.

90 Ibid.

91 See Heiner, above n 32, 285.

92 The governing body is the party in the best suited to carry the burden to investigate and assess developments in knowledge of risks and to take precautionary measures. See Opie, above n 16, 214.

93 See Hanna and Kain, above n 19, 11.

94 Ibid 12. 
reported concussion symptoms. ${ }^{95}$ One of the reasons for this statistic could be the 'machismo' effect-a societal glorification of footballers, where participation in sport sets the boundaries for appropriate masculine behaviour and hierarchy, relegating personal health and safety as secondary issues. ${ }^{96}$

A counter-argument to this defence could be the player's lack of compos mentis immediately following a concussion. It has been suggested that asking the player whether he is able to return-to-play is not a definitive guide due to the possible post-traumatic amnesia suffered by the player. ${ }^{97}$ Financial concerns surrounding the lack of post-injury payments and missing performance bonuses have also been advanced as factors that might influence the player's decision. ${ }^{98}$

\section{Responses to concussion in Australia}

Concussion in professional football has been on the radar in Australia for a number of years and the actions of both the AFL and the NRL have significantly contributed to raising awareness of the seriousness of the issue. ${ }^{99}$ However, the weekly round-up of football often contains reports on concussed players, reflective of the inherent risks associated with full contact football. ${ }^{100}$ Suggestions have also been made that the media portrayal of concussion minimises the issue, with media comment focussing on the speed with which the injured players return to play, rather than the seriousness of the injury. ${ }^{101}$

Both the AFL and the NRL have introduced rule changes relevant to their respective codes in terms of return-to-play decisions and player sanctions, and independently embarked upon research into the effect of multiple concussions on professional football players.

At the end of the 2010 season, the AFL amended the interchange rule. One of the objectives of the amended rule was to reduce congestion on the field and minimise the risk of injury. ${ }^{102}$ The AFL Medical Officers' Association has developed guidelines on the management of concussion, based upon research undertaken by Dr Michael Makdissi and Associate Professor

95 See Howard Fendrich, 'NFL Players Hide, Fear Concussions', AP Impact, ABC News (online), $<$ http://abcnews.go.com/Sports/wireStory?id=9123270>.

96 Where participation in sport is viewed as machismo and coupled with the limited career span of a player, results in player health issues ranking second. See Hecht, above n 13, 36 .

97 Ibid 52.

98 Some contractual payment terms, such as performance bonuses, might also contribute to players withholding their concussion symptoms. See Hanna and Kain, above n 19, 12.

99 The AFL has been recording injuries for the past 19 years and participated in the $3^{\text {rd }}$ IOC World Conference on Prevention of Injury and Illness in Sport in April 2011. See Assoc. Prof. John Orchard and Dr. Hugh Seward, 2011 Injury Report Australian Football League (2011), 1.

100 See Jennifer Witham and Luke Holmesby, 'Multiple Concussions a Concern', AFL (online), 23 July $2010<$ http://www.afl.com.au/tabid/208/default.aspx?newsid=98791>.

101 Studies have been done of the incidence and management of concussion in the National Rugby Leagues Telstra Premiership in 2010. See Tracey L McLellan and Audrey McKinlay 'Does the way concussion is portrayed affect public awareness of appropriate concussion management: the case of rugby league' British Journal of Sports Medicine (online), 3 May 2011,

$<$ http://crlnsw.com.au/fileadmin/user_upload/National_Sports_Trainers_Scheme/Mclellan_etal_2011 Does the way concussion is portrayed affect public awareness of appropriate concussion ma nagement the case of rugby league BrISportMed.pdf $>$.

102 See New Interchange Law \& Procedures 2008, Australian Football League, provision 7.2. The rule was passed in 2008 and amended prior to the 2011 season. Above n 98, 16. 
Paul McCrory. ${ }^{103}$ In March 2011, the AFL announced rule changes to prohibit players from returning to play when the player suffered signs of concussion. ${ }^{104}$

A number of studies are currently underway into the effect of multiple concussion and return-to-play guidelines. ${ }^{105}$ The AFL has implemented the use of pre-season cognitive testing and has adopted the SCAT 2 testing system endorsed at the $3^{\text {rd }}$ World Concussion Congress. ${ }^{106}$

The NRL's stance on concussion management gained momentum earlier this year with the introduction of mandatory concussion guidelines, following the AFL's lead. ${ }^{107}$ It has mandated the use of the CogState Sports System ${ }^{108}$ by all clubs funded by the NRL for baseline measure of player cognition and has adopted the SCAT2, for determining if a player has suffered a concussion. ${ }^{109}$ On the research front, the NRL has commissioned Dr Richard Parkinson, an Australian neurosurgeon, to conduct a two-year research project in the United States on concussion. Dr Parkinson is half-way through this research and spoke publically about the issue recently. ${ }^{110}$ In July 2011, the NRL announced that new rules were being implemented to empower the Chief Medical Officer to investigate and fine clubs where players likely to have suffered concussion are being permitted to return to play. ${ }^{111}$

\section{Legal Issues}

A review of past authorities suggests a reluctance to hold governing bodies liable in cases involving personal injuries litigation arising from inherently dangerous contact sports like football. ${ }^{112}$ The view prevails that all players are vulnerable when playing high-contact sports; that adults who voluntarily participate in inherently risky sports are taken to be aware of the risks. ${ }^{113}$ However, in claims against governing bodies, the authorities have focussed on

103 Both researchers have extensive research experience in concussion in professional football. Dr Makdissi (University of Melbourne) was the recipient of the AFL Research Funding Program and team doctor for the Hawthorn FC. Professor Paul McCrory is a member of the Centre for Health, Exercise \& Sports Medicine (University of Melbourne) and co-authored the three Consensus Statements following the $1^{\text {st }}, 2^{\text {nd }}$ and $3^{\text {rd }}$ Concussion Conferences held in Vienna (2001), Prague (2004) and Zurich (2008). Both presented at the $3^{\text {rd }}$ IOC World Conference on Prevention of Injury and Illness in Sport. Above n 98, 3.

104 AFL Research Board, The Management of Concussion in Australian Football, AFL Medical Officers' Association, April 2011.

105 Above n 98, 16.

106 Sport Concussion Assessment Tool 2.

107 The major policy shift in 2011 was the introduction of the return-to-play guidelines which prohibit a player from returning to play in the event of concussion. See NRL, 'NRL Mailbox: The truth about injuries' NRL.com (online), 30 March 2011, <http://www.nrl.com/NewsViews/LatestNews/NewsArticle/tabid/10874/newsId/62020/Default.aspx $>$.

108 This is an Australian publicly listed company. See ASX Announcement, NRL mandates Use of CogState Sport For Concussion Management, 1 April 2011.

109 See PBS Frontline Backgrounder, 'Concussion Rules', PBS (online), 24 May 2011 $<$ http://www.abc.net.au/4corners/content/2011/s3225219.htm>.

110 See ABC Four Corners, Brain Explosion, 19 May 2011.

111 Brent Read, 'NRL to tighten rules on concussion', The Australian (online), 14 July 2011 $<$ http://www.theaustralian.com.au/news/sport/nrl-to-tighten-rules-on-concussion/story-e6frg7mf$1226094192943>$.

112 See for example, Agar v Hyde (2000) 201 CLR. 552; Haylen v New South Wales Rugby Union [2002] NSWSC 114; Green $v$ Country Rugby Football League of New South Wales [2008] NSWSC 2; Malo v South Sydney District Junior Rugby Football League [2008] NSWSC 552.

113 See Opie, above n 16. 
voluntary participation, rather than participation as part of a 'day' job. ${ }^{114}$ The window left open in Agar $v$ Hyde, ${ }^{115}$ where a duty might exist based on an employer-employee relationship and based on a sports injury occurring at 'work', is an area worthy of further consideration. ${ }^{116}$

The true relationship of the governing bodies to the players will need to be analysed. Issues such as the degree and extent of influence and control will need to be reviewed to determine the true nature of the relationship and whether any 'joint employer' doctrine might arise. ${ }^{117}$ This argument might be strengthened in situations where the parties are under a tripartite agreement (between the governing body, the club, and the player).

It will be interesting to see if any parallels could be drawn with the parent-subsidiary relationship in a corporate law context, ${ }^{118}$ and whether the governing bodies have sufficiently strong degrees of control and influence over their clubs to raise a duty of care. ${ }^{119}$ This nexus has been examined in the context of rugby union, particularly in issues of practical control by the governing body (akin to the parent) over the lesser governing bodies (akin to the subsidiary). Suggestions have been raised, albeit in the context of rugby union, that the ability of governing bodies to control and direct the activities of teams might give rise to a direct duty to players. ${ }^{120}$ Issues such as responsibility for workplace safety have been raised as suggestive of a closer, more proximate relationship. ${ }^{121}$ If an employment relationship can be established, the consequential obligations follow, including obligations to adopt special precautionary measures where an employer knows or ought to have known of an employee's vulnerability. ${ }^{122}$ The question of knowledge and notice might be raised to determine whether the emerging scientific research (being conducted in the United States from 2002) produced the appropriate response from the Australian governing bodies. ${ }^{123}$

Apart from the obvious challenges associated with proving the elements of negligence, including the existence of a duty and causation, other legal issues include questions of jurisdiction and relevant limitation periods or extensions of such limitation periods. ${ }^{124}$

The English courts have shown a willingness to break new ground in regard to sports-related injuries in the professional arena. Governing bodies possessing special knowledge with respect to risk have been held to owe a duty of care towards the participants as a defined

114 There are difficulties in drawing distinctions between the professional and semi-professional football. See ibid 221 and reference to Wickham v Canberra District Rugby League Football Club (1998) ATPR 41-664.

115 Agar v Hyde (2000) 201 CLR 552, 685.

116 It has been suggested that the Court, in obiter, indicated that it could revisit the issues again in circumstances where the injured person was an employee. See Opie, above n 16, 219.

117 See Heiner, above $\mathrm{n} 32$.

118 This issue was examined by Rogers AJA in Briggs $v$ James Hardie \& Co Pty Ltd (1989) 7 ACLC 84.

119 See CSR $v$ Young [1998] Aust Tort Reports 81468 where the degree of control was such that the Court held that the controlling company itself effectively conducted the subsidiaries activities and the subsidiary was merely a conduit for the parent company.

120 See Opie, above n 16, 224.

121 See James Hardie E Co Pty Ltd v Hall (1998) 43 NSWLR 554.

122 See Danuta Mendelson, The New Law of Torts (Oxford University Press, $2^{\text {nd }}$ ed, 2011) 343.

123 See Opie, above n 16.

124 The state and territory limitation legislation in Australia provides for extensions of the limitation periods but in a variety of ways. In Queensland, for example, s. 31 Limitations of Actions Act 1974 allows an extension if a material fact of a decisive nature comes to the plaintiff's attention to establish a cause of action. A material fact can include the fact that the negligence or breach of duty has caused the personal injury: s 30(1)(a), Limitations of Actions Act 1974 (Qld). See Frances McGlone and Amanda Strickley, Australian Torts Law (LexisNexis Butterworths $2^{\text {nd }}$ ed, 2009) 326. 
class of person, with knowledge of the participant's reliance on that advice in a defined situation. ${ }^{125}$ In formulating these principles, the English courts have looked at a number of distinctive features including the sport itself, the structure of the governing body, the involvement the governing body has in safety and reliance by the participants. ${ }^{126}$ Commentators have suggested that there are wide implications of the English approach for sports such as rugby where the risk of serious injury is present. ${ }^{127}$ Whether this will occur in Australia is yet to be tested in the context of professional sport and governing bodies.

\section{A United Front}

Both the AFL and the NRL have recently taken positive steps toward implementing guidelines in an effort to minimise the risk of concussions. By engaging highly qualified researchers to undertake complicated scientific studies into concussion, they have shown that the issues are serious and have raised awareness internally. By modifying the rules and increasing the sanctions, they have shown that player safety is of utmost concern. However, a broader public and player awareness campaign might be warranted in order to raise awareness of the serious nature of concussion, to distinguish from other repairable injuries, and to foster the understanding that there is no such thing as a 'minor concussion'. ${ }^{128}$

As referenced above, both the AFL and the NRL have, through their respective medical committees, developed guidelines for the management of concussion. Unlike the allegations mounted against the NFL, there is no suggestion that these guidelines are based on flawed research. The actions by the AFL and the NRL recognise the duty to protect the players' health and safety and to implement risk management strategies. However, both bodies need to continue to work to ensure the implementation, compliance, and enforcement of the guidelines, as well as consistent application of penalties and sanctions. ${ }^{129}$ To maintain the highest degree of transparency, an independent review of implementation, compliance, and enforcement of the guidelines would be of benefit in the future to repel suggestions of impropriety.

\section{Conclusion}

Concussion is concussion, regardless of whether it occurs in Australian Rules football or rugby league, or any other sport for that matter. If this is truly a player health and safety issue, with commercial considerations aside, a unified approach could send a strong message. As Christopher Nowinski recently proclaimed: 'It's not just an American problem; it belongs to Australia'. ${ }^{130}$

125 See, eg, British Boxing Board of Control v Watson [2001] QB 1134, where the Board was liable in damages to a professional boxer in failing to ensure immediate medical treatment was available on site. See Tim Kevan, Dominic Adamson, Stephen Cottrell, Sports Personal Injury: Law and Practice (Sweet \& Maxwell 2002) [10.04].

126 Ibid [10.07].

127 Ibid [10.27].

128 See Cantu, above n 28. This might also go towards eliminating the 'machismo' effect - by showing the gruesome effects of concussion, to bring about a change in priorities.

129 See Kevan, above n 125 [10.28]. Interestingly, the possibility was raised of a breach of Article 2 of the European Convention of Human Rights as applying to governing bodies. Article 2 provides a right to life and might apply for example to the provisions of adequate medical facilities.

130 Christopher Nowniski, former professional wrestler and footballer, co-founder of Sports Legacy Institute. See Nick Walshaw, 'NRL players to donate brains' News.com.au (online), 30 April 2011, $<$ http://www.news.com.au/national/dead-nrl-player-brains-used-in-study/story-e6frfkvr$\underline{1226047549750 />\text {. }}$ 
It has been suggested in the United States that American society needed an increase of concussion-related litigation to raise awareness and to put sporting franchises, and the NFL, on notice that if they fail to protect the players, they will be vulnerable to legal action. ${ }^{131}$ This prediction recently came true, and possibly gained momentum by the 'Big Tobacco' reference at the Congressional Hearings. ${ }^{132}$ Despite the infancy of the claims, the spotlight is now on these issues.

There are more constructive ways to achieve consensus and outcomes in this debate, as can be seen by the introduction of the Article 65 benefits in the new NFL Collective Bargaining Agreement. Greater awareness and a united approach can lead to better outcomes and preserve the future of the self-regulatory model in the governance of professional football in Australia.

The Maxwell and Easterling claims have a long road to travel before the outcomes will be known, and it will be interesting to watch the litigation unfold or see the settlements announced. ${ }^{133}$ Regardless, one can only speculate that the NFL is shifting uncomfortably in its seat knowing that the public nature of the litigation will focus the spotlight on its conduct and governance. Commentators have already begun speculating that the damage has been donethat the washing will be aired in public. ${ }^{134}$ We recall the degree of public awareness surrounding the McLibel case ${ }^{135}$ and while acknowledging the different nature of the claims, the public appetite for 'David and Goliath' type litigation is insatiable. Add sport to the mix and the reaction potentially becomes explosive.

131 See Hecht, above $\mathrm{n} 13$.

132 Above $n 4$.

133 The NFL has, not surprisingly, stated that the claims will be vehemently defended.

134 See Patrick Hruby, 'Listen, NFL: Settle the Concussions Lawsuit Before It's Too Late', The Athlantic (online), 22 July 2011, <http://www.theatlantic.com/enternainment/print/2011/07listen-nfl-settle-theconcussions-lawsuit-before-its-too-late/242365/>; McCann, above n 89.

135 McDonald's Corporation v Steel \& Morris [1997] EWHC QB 366. 